
$\square$

$\square$

Наведені результати розробки синбіотичного комплексу, який складається з іммобілізованих форм біфідобактерій та інуліну. Досліджено вплив даної добавки на структурно-механічні властивості жсирової начинки і органолептичні показники вафельних виробів. Встановлено збільшення ефективної в'язкості $i$ пластичної мічності начинки. Комбіноване застосування інуліну та іммобілізованих біфідобактерій дозволить покращити консистенцію $i$ смак готових виробів

Ключові слова: іммобілізовані біфідобактеріі, інулін, синбіотичний комплекс, структурно-механічні властивості, вафельні вироби

Приведены результаты разработки синбиотического комплекса, который состоит из иммобилизованных форм бифидобактерий и инулина. Исследовано влияние данной добавки на структурно-механические свойства жировой начинки и органолептические показатели вафельных изделий. Установлено увеличение әффективной вязкости и пластической прочности начинки. Комбинированное применение инулина и иммобилизованных бифидобактерий позволит улучить консистенцию и вкус готовых изделий

Ключевые слова: иммобилизованные бифидобактерии, инулин, синбиотический комплекс, структурно-механические свойства, вафельные изделия

\title{
RESEARCH INTOEFFECT OF THE SYNBIOTIC COMPLEX ON THE QUALITY OF A FAT FILLING FOR WAFFLES
}

\author{
H. Korkach \\ $\mathrm{PhD}$, Associate Professor \\ Department of Bakery, confectionary, \\ macaroni products and \\ food concentrate technologies \\ Odessa National Academy of \\ Food Technologies \\ Kanatna str., 112, Odessa, Ukraine, 65039 \\ E-mail: kor2007@ukr.net
}

\section{Introduction}

A growing number of Ukrainians are changing their preferences in food, showing increased interest in the products that are most beneficial for health, basing their choice not on the amount of food consumed but rather its quality.

Food and nutrition occupies a leading place in enabling normal growth and development of the body, protecting it from diseases and harmful influences, maintaining physical and psycho-emotional activity and active longevity.

There is a close relationship between a human's healthand composition of his intestinal microflora. Microflora of the intestine is involved in the symbiotic digestion, inactivation of excessive digestive secretions and enzymes, and in the processes of synthesis of the most important nutrients and endogenous regulatory factors [1].

The most important function of the microflorais the transformation, activation, digestion, circulation, inactivation, discharge (Fig. 1)

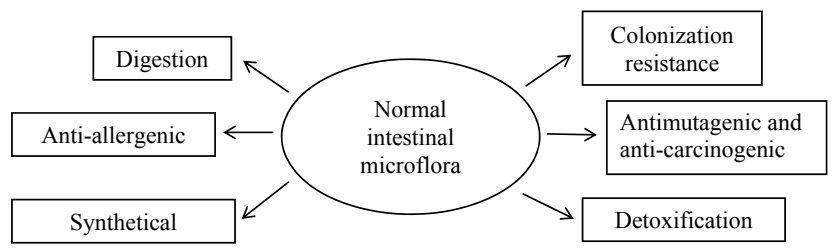

Fig. 1. Functions of normobiocenosis of GIT
Economic development of the planet is accompanied by the introduction into life of ever-growing number of chemical compounds with potential toxic effect on the microbial population. These include organic and inorganic compounds, medical preparations, pesticides, food additives. Ukraine, due to a significant depreciation of production funds of enterprises, constantly faces conditions for the occurrence of various technogenic disasters. This is accompanied by the penetration of harmful compounds into the environment. At present, most of the country's population breathe atmospheric air that contains xenobiotics.

Many household-drinking water supply pipelineslack systems for water pre-treatment and decontamination. All these conditions, as well as antibiotic therapy, the intake of hormonal, immunosuppressive, laxative, choleretic and other medicines, irrational nutrition, stresses, intestinal infections, adverse exoecological conditions, lead to the development of dysbiotic disorders of the intestine (Table 1) [2].

It is estimated by physicians that from 75 to $90 \%$ of our fellow citizens in one way or another are prone to intestinal dysbacteriosis, that is, it is possible to argue about a pandemic of dysbacteriosis. That is why the products of functional designation, containing in their composition special ingredients that correct disturbance of intestinal microflora, take one of the top places in comprehensive prevention of diseases, at which the dysbiosis is registered. Functional ingredients contained in the product's composition include synbiotics [3]. 
Table 1 of inulin and oligofructose. The introduction to the formu-

Causes and factors underlying the development of dysbacteriosis

\begin{tabular}{|c|}
\hline Exogenous: \\
\hline Professional (industrial contamination) \\
\hline sanitation \\
\hline physical and chemical \\
\hline climatic-geographical \\
\hline Endogenous: \\
\hline immune disturbance \\
\hline stress conditions \\
\hline $\begin{array}{l}\text { somatic diseases (diseases of the intestine, ulcer of stomach and } \\
\text { duodenum, resection of the stomach, disease of gall bladder and } \\
\text { biliary tract, liver and pancreas) }\end{array}$ \\
\hline infectious diseases \\
\hline intestinal ischemia \\
\hline diabetes mellitus \\
\hline old age \\
\hline irrational nutrition \\
\hline hunger \\
\hline $\begin{array}{l}\text { medical impact (antibiotics, preparations, locally anesthetizing, } \\
\text { adsorbent substances and other means can change the motor of } \\
\text { mucous, break the formation of mucin) }\end{array}$ \\
\hline
\end{tabular}

Synbiotics are a combination of the pro- and prebioticsthrough which they exerta mutually reinforcing influence on the physiological functions and metabolic processes in the human body. Designing confectionery products with a rationally chosen composition of probiotic microorganisms, prebiotics as functionally active ingredients whose deficit is a consequence of the dysbiosis, is a reasonable approach to solving this important problem.

\section{Literature review and problem statement}

Under conditions of tough competition, manufacturers of confectionery products realize that survival in the market environment is impossible without the creation of products of high quality and functional designation.

Up to now, however,Ukrainian confectionery industry hasfailed tomanufacture products using pro-, prebiotics, and synbiotics. At the same time, the Russian company "Art Life" developed a series of candies, enriched with the probiotic cultures of microorganisms. They are recommended for consumption as an affordable preventive means. The result of consumptionis maintaining intestinal microflora, normal digestion and renewed microflora after a course of antibiotic use, dysbacteriosis of different etiologies, at intestinal infections [4].

A fat filling for flour pastry was also developed with a full replacement of sugar with palatinoza and the introduction of Jerusalem artichoke powder in the range of $7 \%$ as itpossesses prebiotic properties. The studies conducted have shown that the introduction of palatinoza and the Jerusalem artichoke powder affected physical-chemical properties of the fat filling, as well as on rheological and organoleptic characteristics. The devised technological techniques made it possible to obtain the filling with a reduced fat content and with improved physiological value [5].

Paper [6] reported studies into reducing energy value and sugar content by replacing sugar and part of fat with the sweet agent Beneo ${ }^{\mathrm{TM}}$ Synergy1, consisting of the powder lationof this supplement as a sweet agent makes it possible toobtain aconfectionary product with dietary and prebiotic properties.

A possibility of usingthe dietary fibers (DF) Citri-Fi was investigated for producing fat fillings in order to reduce fat content of the product. The obtained results show that DF, in additionto functionality, have high moisture-binding and fat-binding capacity, they produce a positive effect on the structure of fat and can be employed in the composition of a fat formulation [7].

Researchers studied the possibility of obtaining wafers with the use of the prebiotic fiber inulin. They investigated samples of a fat filling with the introduction of various mass fraction of theprebiotic. The obtained experimental data on determining the impact of inulin on the rheological properties of a semi-finished product and organoleptic indicators of the finished products indicate the prospects forintroducing the givenadditiveto the formulation of a fat filling [8].

Themoisture-resistant waffles are proposed, which contain a small amount of sugar. The composition of waffles includes $0 \ldots 8 \%$ of sucrose, starch hydrolysate, inulin hydrolysate, and a mixture. The waffle composition is additionally added with proteinase and/or xylanase. In addition, the liquid batter is supplemented with $0.0005-1.0 \%$ of heatresistant $\alpha$-amylase. Fat content in waffles is $<4 \%$ [9].

There have been developed new types of fat filling with introduction to the formulation of bifidobacteria and lactobacillus as probiotics. Conducted experiments have shown that the introduction of probiotic microorganisms provides consistent quality of finished products and makes it possible to effectively regulate duration of the technological process [10].

It was proposed to use in the formulation of a fat filling the probiotics - Bifilakt A and Bifilakt D, as well as theprebioticBeneo ${ }^{\mathrm{TM}}$ Synergy1. The paper investigated the effect of additive on the rheological properties of the model system and determined optimum amount of the additive in order to obtaina high-quality filling [11].

In article [12], authors conducted a study on the introduction of pro-, prebiotics, and synbiotics to the formulation of chocolate. They explored the positive and negative aspects of the designed functional products in comparison with the standard products. It was concluded that the obtained results had to be confirmed byin vitro and in vivostudies.

Scientists have developed a synbiotic based on the microorganisms $B$. indicus HU36 and food fibers (FF) maltodextrin and lemon fiber. The influence of the additive on the organoleptic properties of dark chocolate was examined. Authors studied the survival of microorganisms when introduced to the formulation of chocolate. They proved the impact of FF on the sensory properties of the finished product: sweetness and firmness [13].

In paper [14], milk chocolate was prepared by introducing free or encapsulated Lactobacillus casei NCDC 298 and inulin. The number of Lactobacillus remained above $10^{8} \mathrm{cfu} /$ gover the period of storage of 60 days. It was discovered that the introduction of these ingredients helps to improve microbiological properties of the finished product during storage. A sensory analysis has confirmed good taste indicators of chocolate with synbiotic properties.

Paper [15] presentedvarious possibilities for enriching bakery and confectionery products with probiotic microorganisms. In particular, a confectionary cream, enriched with six kinds of microorganisms. It was examined that they 
retain their viability after storing at a temperature of $20^{\circ} \mathrm{C}$. The probioticconfectionary cream has a pleasant slightly sour taste.

Article [16] reports studies on using synbiotics in the technology of nougat. Synbiotic complex was developed based on aprobiotic - microorganisms of the Bacillus coagulans family and a prebiotic - the low-calorie sweeteners isomalt and sorbitol. The authors investigated the survival of bacteria at high temperature and after a long period of storage of the finished product. The influence of prebiotic on the texture of nougat was examined. They also studied the survival of bacteria over the entire period of shelf life of the finished product. It was established that in 6 months the number of living cells of the microorganisms was $10^{6} \mathrm{cfu} / \mathrm{g}$.

Thus, the above works considered the introductionto the formulation of various confectionery products of pro- and prebiotics. It should be noted that there are practically nostudies aimed at developing the synbiotics and exploring their impact on the quality of finished products. The papers report results on the introduction of probiotics totheformulations ofconfectionary products, but fail to take into account the effect of technological factors on their survival. There is no research into techniquesthat "protect"microorganisms from the unfavorable factors.

We developedat Odessa National Academy of Food Technologies (Ukraine) the symbiotic complex, which consists of the immobilized forms of bifidobacteria and inulin. Employing it in the technology of waffle products opens up new pathways to create products with functional properties. That is why it is advisable to examine the influence of synbiotic on the structural-mechanical and organoleptic quality indicators of a fat filling.

\section{The aim and objectives of the study}

The aim of present work is the scientific substantiation of creating asymbiotic complex and experimental confirmation of the feasibility of using it in the technology of a fat filling.

To achieve the set aim, the following tasks have been solved:

- to develop a synbiotic complex based on the immobilized bifidobacteria Bifidobacterium bifidum and the prebiotic inulin;

- to determine effect of the synbiotic complex on the structural-mechanical and organoleptic properties of a filling for waffles;

- to assess consumer properties of the obtained waffle products.

\section{Materials, objects, and methods of research}

The object of research is the organoleptic, physical-chemical properties of the fat filling. The subject of research is a fat filling with the synbiotic complex - we used microencapsulated bifidobacteria as the probiotic, and inulin as theprebiotic. The samples differed by the mass fraction of inulin (10, 20 and $30 \%$ ofinulin). We used the wafers "Artek" as a control.

The examined materials and research methods are described in detail in [17].

\section{Results of research into organoleptic, physical-chemical properties of a fat filling with thesynbiotic complex}

\section{1. Design of the synbiotic complex for a fat filling}

One of the most important groups of symbiotic microflora of the human is the genus Bifidobacterium. Representatives of this genus are the natural inhabitants of the large intestine of children and adults. In this case, many species exert a considerable number of positive effects on the owner's body [18]. Bifidobacteria, which are constantly present in the gastrointestinal tract and mucous of the human, participate in the morphogenesis and functions of different systems of the host's organism - digestive, immune, cardiovascular, endocrine, etc. This happens due to the participation of bifidobacteriain the metabolism of proteins, lipids, carbohydrates, as well as due to the large number of produced biologically active substances: enzymes, extracellular proteins, polysaccharides [19-21].

It was found that bifidobacteria perform the following functions:

- theycarry out physiological protection of the intestinal barrier against penetration of germs and toxins inside the internal environment of the bodyby associating with the bowel's mucous membrane;

- they possess high antagonistic activity against pathogenic and conditionally pathogenic microorganisms due to the generation of organic fatty acids;

- they take part in the recycling of food substrates and activation of parietal digestion;

- they synthesize amino acids and proteins, vitamin $\mathrm{K}$, pantothenic acid, the $\mathrm{B}$ group vitamins: $\mathrm{B}_{1}$ - thiamine, $\mathrm{B}_{2}-$ riboflavin, $\mathrm{B}_{3}-$ nicotinic acid, $\mathrm{B}_{6}-$ pyridoxine [22].

Until recently, in order to prevent and treat dysbacteriosis, the pharmacopoeia alpreparations and/or functional food products were consumed, which include probiotic microorganisms in their composition. It is generally known, however, that bifidobacteria are the anaerobic microorganisms, that is, the bacteria that live in the oxygen-free environment. They are also very sensitive to acidic environment and temperature impacts. In addition, bifidobacteria occupy a very specific ecological niche in the biocenosis of the "owner's" bowel. That is why the designers of products with functional properties facethe following problems in terms of survival and delivery of bifidobacteria to the large intestine (Fig. 2).

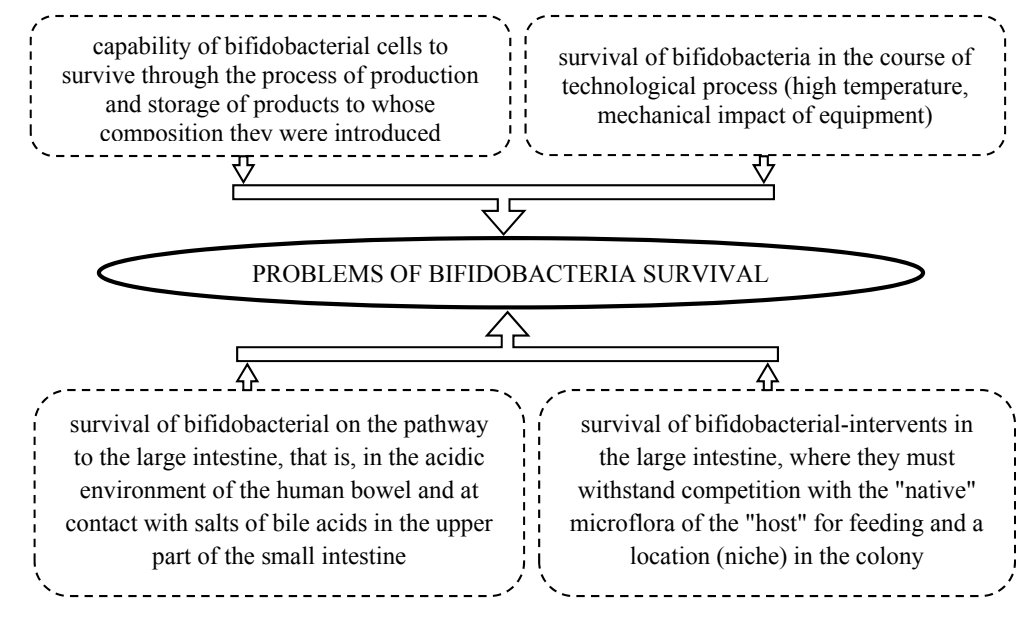

Fig. 2. Problems of the bifidobacteri a survival 
The decision was made to "protect" thecells of bifidobacteria from the effects of adverse conditions. To do this, authors of $[23,24]$ employed the process of immobilization and obtained the microcapsules with bifidobacteria coated with a protective sheath.

There was also another technique to influence the intestinal microflora. It is based on the properties of certain food materials to reach, unchanged, thelarge intestine, where they serve as the breeding medium for bifidoflora. These substances are called bifidogenic or prebiotic.

Inulin was applied as a prebiotic in the studies on designing the synbiotic complex. Inulin is the organic matter of polysaccharides, which is received as a result of processing roots and tubers of some plants. One of the most important properties of inulin is that it withstandsthe effect of digestive enzymes that are found in our stomach. Inulin has a slightly sweet taste, a neutral color and smell, it improves the volume, texture and taste of the product. It forms a white opaque soft cream-like gel that mimics the texture of fat. It possesses high solubility and thermal stability, has moisture-retaining properties, increases stability of the emulsion, improves the organoleptic and physical-chemical characteristics of the finished product.

The molecules ofinulin, while entering the digestive tract, under the influence of hydrochloric acid, are split into fructose and other elements that penetrate the bloodstream. The unsplit part of inulinis associated with glucose in the blood, reducing thereby the concentration. The unsplit inulin is also bound with ketones, acetones, various toxins, fatty acids and cholesterol, removing them from the human body, providing a beneficial effect on the general health condition [22].

In the large intestine inulin is processed by bifidobacteria. Thus, bifidobacteria receive an exclusive feed supply that provides active growth. Numerous clinical studies, conducted in various countries, showed that in all cases the introduction of inulin led to a substantial increase in the population of bifidobacteria, while suppressing at the same time the pathogenic organisms [25].

Thus, inulin possesses important dietary properties, which make it possible to position the finished food products as the dietary, functional and enriched products. It also has a reduced calorie content of $1 \mathrm{Kcal} / \mathrm{g}$; suitable for the diabetic diet; it possesses important technological properties, which make it possible to obtain products with a reduced fat and sugar content, to improve texture, stability, and taste.

Given the above, we decided to create the synbiotic complex whose composition includes immobilized cells of bifidobacteria as the probiotic, and inulin as the prebiotic.

\section{2. Effect of the synbiotic complex on the structur-} al-mechanical properties of a filler for waffles

Within the framework of present study,we determined the mass fraction of inulinintroduced to the formulation of a fat filling. The mass fraction ranged from 10 to $40 \%$, replacing the equivalent amount of fat. The number of bifidobacteria, which were added to all samples, was determined taking into account that the physiologically-active level of microorganisms in the functional food products should equal $10^{6}-10^{7} \mathrm{cfu} / \mathrm{g}$ of the contents of the intestines.

The samples prepared with $40 \%$ of fat replacedwith inulin possessed higher density and viscosity, whichpreventeduniform applying the filling on wafer. The organoleptic indicators - a dense consistency - also indicated the impossibility of using such an amount of inulin. That is whywe de- cided that the mass fraction of inulin, which is introduced to the formulationof the filling for waffles, is 10,20 , and $30 \%$.

The effect of the introduced components of the synbiotic complex on the rheological characteristics of a semi-finished product - a fat filler - is the factor that enables productionof quality products. It is important that the filler has the required properties for the uniform application on a wafer and stabilization in the process of maturing.

The basic rheological characteristics of fat masses include: boundary effective viscosity; shear stress at which the destruction of structure starts, and plastic strength. Strength describes the capability of shaped products to withstand subsequent mechanical action (glazing, wrapping, etc.). Viscosity characterizes ability of the masses to be shaped in one way or another.

Viscosity depends largely on the temperature of the examined mixture. Prepared filler, before being deliveredfor applying on the wafer sheets, is stored in a tempering machine with its temperature equal to $35^{\circ} \mathrm{C}$.

The experiments were carried out on the rotary viscometer "Reotest-2" with a change in the shear rate within $0.1667-72.9 \mathrm{~s}^{-1}$, temperature of thefillerwas $35^{\circ} \mathrm{C}$. Results of the experiments wereprocessed in accordance with the instructionsto the device.

With the introduction of different mass fraction of inulin and the microencapsulated bifidobacteria to the filler, effective viscosity at a shear rate of $0.1667 \mathrm{~s}^{-1}$ in the control sample was $0.7 \mathrm{kPa} \cdot \mathrm{s}$; and in the examined samples with 10 , 20 , and $30 \%$ of inulin and capsules is, respectively, $0.8 ; 0.9$, and $1.3 \mathrm{kPa} \cdot \mathrm{s}$ (Fig. 3).

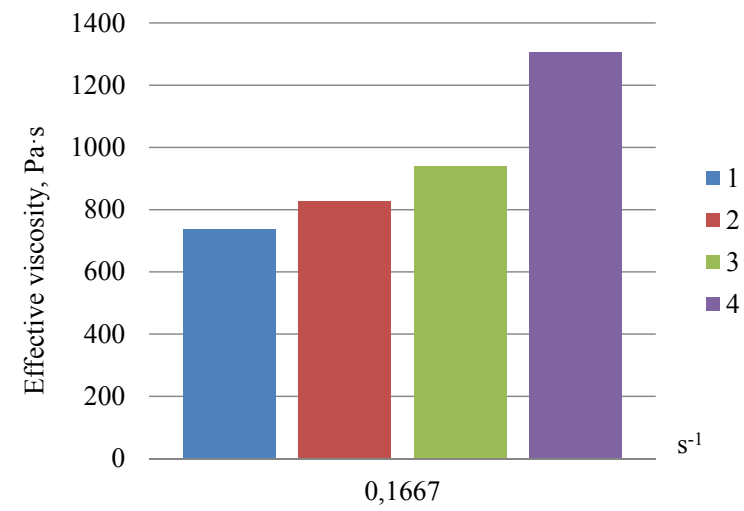

Fig. 3. Effect of the symbiotic complex on a change of effective viscosity with undamaged structure at a shear rate of $0.1667 \mathrm{~s}^{-1}: 1$ - control; $2-10 \%$ of inulin and microencapsulated bifidobacteria; $3-20 \%$ of inulin and microencapsulated bifidobacteria; $4-30 \%$ of inulinand microencapsulate dbifidobacteria

Based on the experimental data, we determined that adding to the fillera symbiotic additive results in the increasing effective viscosity (Fig. 4).

Fat filling in the process or preparation is related to the compact two-phase highly dispersed systems of the coagulation type; after cooling and crystallization of the fat - to thecoagulation-condensation structures.

An important technological process when obtaining the filling is the cooling of wafer layers. A long period ofthe filling hardeningindicates the need for a longer time to cool a wafer layer or a lower temperature of cooling. A long period of cooling can lead to moisturizing because that the relative humidity of air in the cooling chamber is not less than $92 \%$. 
Therefore, it was important to explore the process of structure formation of a wafflefiller.

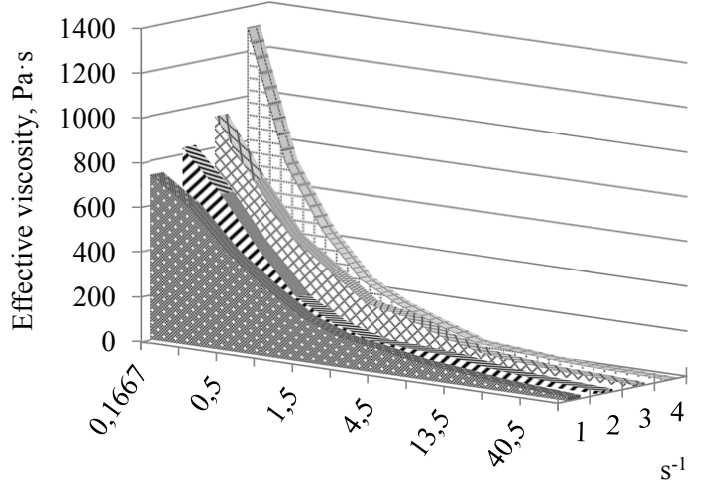

$\bowtie 3$

Fig. 4. Dependence of effective viscosity $\eta$ of the filler on the shear rate gradient $\mathrm{D}$ with a different contentof inulin, \%: $1-0 ; 2-10 ; 3-20 ; 4-30$, and the according number of microencapsulated bifidobacteria

Physical-mechanical properties of the filler for waffles are characterized by themagnitudeof boundary shear stress when the penetrometer cone penetratesthe bulk of the filler and is an objective indicator that reflects resistance of the material to shift and displacement. That is why the penetration properties of the material are related to its structural strength, which may be estimated quantitatively by the boundary shear stress $-\tau_{\mathbf{0}}$.

We investigated effect of the synbiotic on strength of the filling depending on the mass fraction of inulin and bifidobacteria.

An important factor for the successful production of waffles is the process of filling stabilization during maturing of the products. In this connection,we discovered and mapped on the chartthe dependenceof a changein the boundary shear stressof the filler during maturing. A change in the boundary shear stress was determined over the duration of structure formation from 0 to 14 minutes every 2 minutes. The received results are shown in Fig. 5.

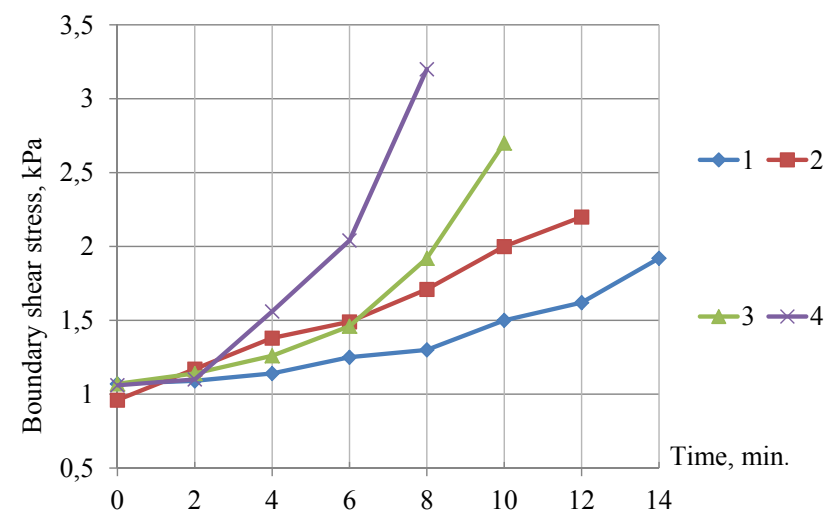

Fig. 5 . Change in the boundary shear stress, $\tau_{0}$, with a different content of inulin, $\%: 1-0 ; 2-10$;

$3-20 ; 4-30$, and the corresponding number of microencapsulated bifidobacteria

In the manufacture of a fat filling, of great importance is the degree of its sticking to the surface of production equipment and a close fit of thewafer layer to the filling.
The formation of adhesive bond between the filling and the surface of a wafer sheetiscrucially affected bythe rheological properties of thefilling, duration and tension of the previous contact, a waffle sheet temperature,the temperature of thefilling, the technique and rate of tear. Adhesion is the phenomenon that occurs during a contact between two dissimilar materials.

Results of the study intoa changein specific tear force Tof the plate on mass of the filling with a synbiotic complex are shown in Fig. 6.

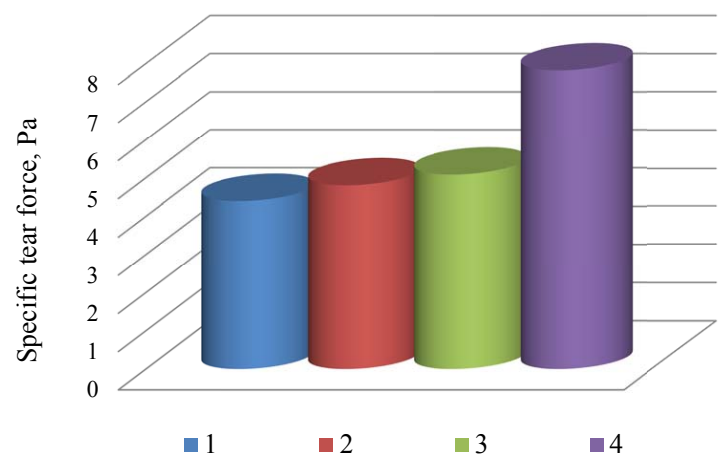

Fig. 6. Dependence of specific tear force T, samplesof the filling with a content of inulin, \%: $1-0 ; 2-10$;

$3-20 ; 4-30$, and the corresponding number of microencapsulated bifidobacteria

In the present work, we examined a change in the density of a waffle fillingintroduced with the symbiotic complex. Experimental results of the study into dependence of density of the filling on the mass fraction of inulin and the corresponding number of immobilized bifidobacteria are shown in Fig. 7.

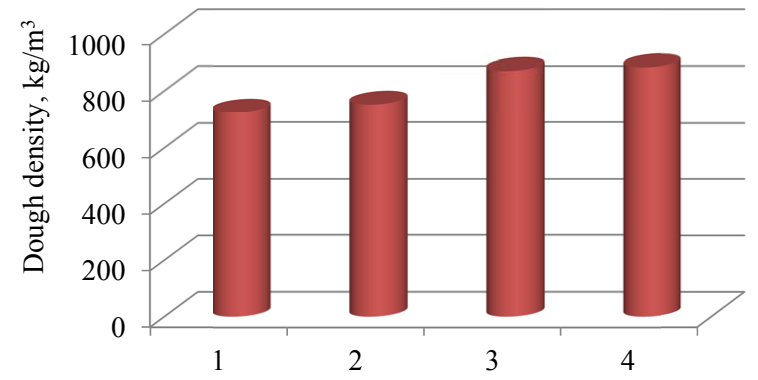

Fig. 7. Change in density of the filling introduced with the synbiotic complex: 1 - control; $2-10 \%$ of inulin and microencapsulated bifidobacteria; $3-20 \%$ of inulin and microencapsulated bifidobacteria; $4-30 \%$ of inulin and microencapsulated bifidobacteria

In the examined samplesof the filling introduced with the synbiotic complex,there occurs a reduction in the mass fraction of fat, which contributes to the saturation of the masswith air. That is why there is an increase in the density of the examined samples of the filling compared to the control. A fat filling is the multiphase structured dispersed system whose composition includes the solid, liquid and gaseous phase. The latter is formed in the process of stirring the mass and due to the capturing and holding the bubbles of air.

5. 3. Evaluation of consumer properties of the obtained waffles

At the next stage of research, we conducted a comprehensive assessment of consumer properties of the designed waffles. 
Effectiveness of the designed formulations and technological modes of manufacture of waffleswith fat fillings for functional purposeswere confirmed bythe experimentaland industrial tests at the facilities of Ltd. "Agrobusiness" and Ltd. "Charivny karavay" (Ukraine).

Organoleptic indicators of the developed type of waffles with the synbiotic complex are given in Table 2.

Table 2

Organoleptic indicators of waffle quality

\begin{tabular}{|c|c|c|}
\hline $\begin{array}{c}\text { Indicator } \\
\text { name }\end{array}$ & Control & "Perlynka" \\
\hline Taste & $\begin{array}{c}\text { Sweet, } \\
\text { without foreign flavor }\end{array}$ & $\begin{array}{c}\text { Less sweet, } \\
\text { no fat taste, crisp }\end{array}$ \\
\hline Aroma & $\begin{array}{c}\text { Peculiar to this type of } \\
\text { product, no foreing smell } \\
\text { and flavor }\end{array}$ & $\begin{array}{c}\text { Peculiar to this type of } \\
\text { product, no foreign smell } \\
\text { and flavor. Waffles are } \\
\text { distinguished by pleasant } \\
\text { aroma }\end{array}$ \\
\hline Color & $\begin{array}{c}\text { Color of the sheet is light yellow, in the section - } \\
\text { combined. Color of the filling is uniform, white }\end{array}$ \\
\hline $\begin{array}{c}\text { Structure } \\
\text { when } \\
\text { broken }\end{array}$ & $\begin{array}{c}\text { Wafer sheets are evenly baked, with } \\
\text { well-developed porosity, with crispy properties, } \\
\text { the filling is evenly distributed }\end{array}$ \\
\hline $\begin{array}{c}\text { Physical } \\
\text { appearance, } \\
\text { surface }\end{array}$ & $\begin{array}{c}\text { Surface with a clear pattern, with an even cut, no } \\
\text { leaks. The filling in wafflesis not over the edge. }\end{array}$ \\
\hline $\begin{array}{c}\text { Filling's } \\
\text { consistency }\end{array}$ & $\begin{array}{c}\text { The filling has } \\
\text { The filling has uneven } \\
\text { consistency without } \\
\text { lumps, though they } \\
\text { sometimes appear, buttery, } \\
\text { does not shift wafer layers }\end{array}$ & $\begin{array}{c}\text { Tomogeneous soft } \\
\text { consilytency, it melts } \\
\text { In the finished product, } \\
\text { it is dense, does not } \\
\text { shiftwafer layers }\end{array}$ \\
\hline
\end{tabular}

Conditions for the development of market economy in Ukraine dictate the necessity to consider in the course of research not only physiological needs of the population but also competitiveness of the proposed products. And since the consumer,when choosing the products, is guided primarily by the organoleptic indicators,it is appropriate to a priori rankthe factors that determine the organoleptic indicators of consumer appeal of the finished goods. Experts unanimously assignedthe first place by importanceto the taste of flour confectionary products, with the second place taken by aroma. That is why, judging by the distribution of ranks, the most important criterion for evaluatingflour confectionary products is the taste of the product.

In order to defineorganoleptic parameters that characterize consumer's appeal ofthe product, we applied a systems approach tothe finished products. The attributes (descriptors), based on which the products were evaluated, were devisedin line with the results of discussion by members of the tasting board. The taste of the product was accepted to be the object of study.

Based on the results of tasting, weconstructed a diagram of the products' taste.

Fig. 8 shows profilogramof taste of waffles (control and the oneintroduced with the symbiotic complex "Perlynka").

Results of the organoleptic analysis showed that the examined samples of waffles positively differed from the control. They possess the filling with a more tender consistency, no lumps, no fat taste.

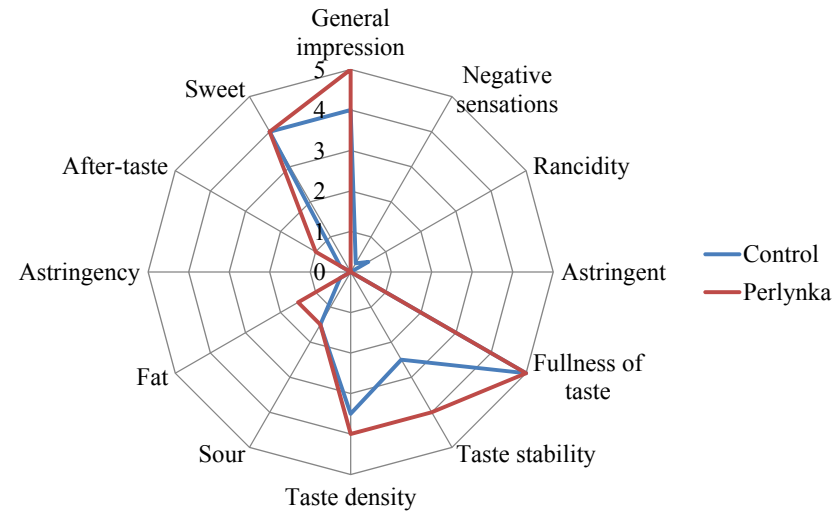

Fig. 8. Profilogramof waffle taste

\section{Discussion of results of examiningeffect of} thesymbiotic complex on quality of a fat filling

As shown by the results of experimental data (Fig. 4), with an increase in thegradient of shear rate effective viscosity of the filler decreases, with the process that occur especially intensively in the range of relatively low shear rates, to approximately $8.1 \mathrm{~s}^{-1}$. With a further increase in the shear rate, the effective viscosity varies slightly. Horizontal sections of the curves correspond to the viscosity of the bulkwhose structure is completely destroyed. In this regard, it follows that obtaining afilling needs to be carried out at such shear rates, at which the structure of the bulkis not destroyed. The maximum shear rate, at which it is possible to receive a good-qualityfilling, matches the beginning of the sectionof smooth transition to the region ofthe destroyed structure. In the given case, this rate amounted to $8.1 \mathrm{~s}^{-1}$.

In practice, the total duration of receiving a high-quality filling is about 15 minutes. Mixing time depends on the nature of the mixed liquids, the mixing frequency, design of the device, and the temperature. As the obtained data indicate, mixing frequency is limited because the structure of a filling is destroyed at speed above $9 \mathrm{~s}^{-1}$.

An increase of effective viscosity in the examined samples of a filling is probably related to that the coagulation structure, created by a dispersive environment, emerges due to the adhesion between particles of theprebiotic fiber of inulin and powdered sugar through thin layers of dispersive environment (fat). With a decrease in the amount of fat in a filling,the fat layer between particles becomes thinner, resulting in the strengthening of the structure and coagulation contacts. That is why, when introducing the synbiotic complex, effective viscosity of the bulk increases.

It was established that reducing the fat content in the bulk and a simultaneous increase in the solid phase leads to an increase in its strength (Fig. 5). Duration of maturing of the finished waffles is reduced becauseduring introduction to the examined samples of the synbiotic additives the plastic strength of filling at structure-formation increases from $1.9 \mathrm{kPa}$ in the control sample to $3.2 \mathrm{kPa}$ in the sample with the dosage of $30 \%$ inulin and microencapsulated bifidobacteria. The experimental data show that the filling of controlsampleacquiresthe requiredstrengthin 14 minutes, whereas for the examined samples this period is $8-12$ minutes.

Strength of the coagulation structures is determined by the number and strength of the solid particles' con- 
tactsper unit volume. An increase in solid particles and a decrease in the thickness of the fat layer leads to the strengthening of the structure. This can be explained by the increasing strength of the fat mass whenasymbiotic complex is introduced.

The obtained experimental data indicate that the application of the synbiotic complex leads to an increase in the force of separation of plate from the samplesof filling introduced withan additive (Fig. 6). This is probably explained by an increase in the filling's plasticity. In the course of technological process, there occursa strong attachment of thefillingto thewafer layers. Over the entire period of storage, the finished products will retain their shape and will not stratify.

The obtained experimental results allow us to assert that the introduction of the synbiotic to the formulation of waffles leads to the improvement of structural and mechanical properties of a semi-finished product. It improves plasticity and viscosity of the filling, shortens duration of maturing of the finished products. Thewaffle fat content reduces. Over the entire period of storage, waffle products will retain their shape and will not stratify. The introduction of the synbiotic complex will provide finished products with physiological orientation, as a result of correction and adjustment of composition and function of the microflora of the digestive tract. This will make it possible to expand the range of flour products for functional purposes intended for peoplewith impaired microecological condition of the body.

Prospects for further research are to determine effect of the synbiotic complex on the state of a fat component of the filling.

\section{Conclusions}

1. Based on the theoretical generalizations, we substantiated a choice of functional ingredients to be introduced to the formulation of a fat filling, which consists of the probiotic microorganisms Bifidobacterium bifidumand the prebiotic inulin. The symbiotic complex was developed experimentally, which consists of the microencapsulated bifidobacteria and inulin. The given synbiotic complex provides a useful effect on the health of the host organism, improving the survival rate in the intestine of live bacterial additives and selectively stimulating the growth and activation of the bifidobacterial metabolism. This will make it possible to create a new kind of the functional fat filling for waffles, capable of restoring the normal microflora of the organism and preventing at the same time a dysbacteriosis.

2. It was established that the introduction of the additivecontributes to an increase in effective viscosity of the mass due to the strengthening of the structure and coagulation contacts. This will help during technological process to better apply and evenlydistributethe filling on the surface of a waffle sheet. The introduction of the synbiotic to the formulation of a fat fillingalsocontributes to an increase in plastic strength of the fat filling. The higher the boundary shear stress (structural strength) of a fat filling, the stronger external mechanical impact it takes to cause a boundary destruction of the structure.

3. Results of the tasting assessment showed that the examined samples of waffles are characterized by improved organoleptic characteristics, have advantages in terms of the indicator"taste", and they do not have a fat taste. The filling is smooth, of tender consistency,and contains neither lumps nor grains.

\section{References}

1. Golin'ko, O. N. Problema ispol'zovaniya probiotikov v produktah lechebno-profilakticheskogo naznacheniya [Text] / O. N. Golin'ko, N. E. Chumak // Problemi harchuvannya. - 2004. - Issue 1. - P. 11-17.

2. Harchenko, N. V. Rol' kishechnoy mikroflory v razvitii hronicheskih zabolevaniy zheludochno-kishechnogotrakta [Text] / N. V. Harchenko, V. V. Chernenko, D. S. Yankovskiy, G. S. Dyment // Zhurnal praktychnoho likaria. - 2003. - Issue 4. - P. $20-27$.

3. Shenderov, B. A. Funkcional'noe pitanie i ego rol' v profilaktike metabolicheskogo sindroma [Text] / B. A. Shenderov. - Moscow: DeLiprint, 2008. - 319 p.

4. Elektronnyy resurs: Kompaniya Art-Layf [Electronic resource]. - Available at: http://www.artlife.tomsknet.ru/

5. Filippova, E. V. Razrabotka zhirovoy nachinki dlya muchnyh konditerskih izdeliy s ispol'zovaniem prebiotikov [Text] / E. V. Filippova, N. A. Tarasenko, A. N. Kurakina // Sovremennye problemy nauki i obrazovaniya. - 2015. - Issue 1. - P. 10-13.

6. Tarasenko, N. A. Inulin i oligofruktoza: effektivnost' v kachestve prebioticheskogo volokna dlya konditerskoy promyshlennosti [Text] / N. A. Tarasenko // Fundamental'nye issledovaniya. - 2014. - Issue 9-6. - P. 1216-1219.

7. Krasina, I. B. Sozdanie zhirovih produktov s vklyuchenim pishchevyh volokon dlya konditerskogo proizvodstva [Text] / I. B. Krasina, I. F. Teslenko, N. A. Tarasenko, Yu. G. Denisenko, P. S. Krasin // Izvestiya vuzov. Pishchevaya tekhnologiya. - 2011. Issue 2-3. - P. 62-63.

8. Korkach, A. V. Obosnovanie vybora funkcional'noy dobavki dlya vafel'nih izdeliy [Text] / A. V. Korkach, Yu. R. Kushnir // Materialy Mezhdunarodnoy nauchno-prakticheskoy konferencii «Pishchevye tekhnologii, Hleboprodukty i kombikorma». Odessa, 2015. - P. 109-110.

9. Par. No. 1982598 EPV. Moisture resistant waver. MPK A 21 D 13/00 [Text] / Nestec S. A., Hansen C. E., Nicolas P., Pamies Valles B. No. 07106604.7; declareted: 20.04.2010; published: 22.10.2011.

10. Krasina, I. B. Vafli s funkcional'nymi svoystvami [Text] / I. B. Krasina, O. I. Dzhahimova, N. A. Tarasenko, A. V. Demidov, O. N. Arakcheeva // Izvestiya vuzov. Pishchevaya tekhnologiya. - 2008. - Issue 1. - P. 41-42.

11. Krasina, I. B. Vliyanie probiotikov i prebiotikov na reologicheskie svoystva strukturirovannyh dispersnyh sistem [Text] / I. B. Krasina, E. A. Hashpakyanc, O. I. Dzhahimova // Fundamental'nye issledovaniya. - 2014. - Issue 6. - P. 1149-1153.

12. Konar, N. Improving functionality of chocolate: A review on probiotic, prebiotic, and/or synbiotic characteristics [Text] / N. Konar, O. S. Toker, S. Oba, O. Sagdic // Trends in Food Science \& Technology. - 2016. - Vol. 49. - P. 35-44. doi: 10.1016/j.tifs.2016.01.002 
13. Erdem, Ö. Development of a novel synbiotic dark chocolate enriched with Bacillus indicus HU36, maltodextrin and lemon fiber: Optimization by response surface methodology [Text] / Ö. Erdem, M. Gültekin-Özgüven, I. Berktaş, S. Erşan, H. E. Tuna, A. Karadağ et. al. // LWT - Food Science and Technology. - 2014. - Vol. 56, Issue 1. - P. 187-193. doi: 10.1016/j.lwt.2013.10.020

14. Mandal, S. Development of synbiotic milk chocolate using encapsulated Lactobacillus casei NCDC 298 [Text] / S. Mandal, S. Hati, A. K. Puniya, R. Singh, K. Singh // Journal of Food Processing and Preservation. - 2013. - Vol. 37, Issue 5. - P. $1031-1037$. doi: 10.1111/j.1745-4549.2012.00759.x

15. Chonova, V. V'zmozhnosti za prilozhenie na probiotici v hleboproizvodstvoto i sladkarstvoto [Text] / V. Chonova // Nauchni trudove na Rusenskiya Universitet. - 2013. - Vol. 52. - P. 213-218.

16. Sarraf, S. Idea till production of functional synbiotic nougaz [Text] / S. Sarraf, H. Sadeghy, M. Shirzad // Research in Pharmaceutical Sciences. - 2012. - Vol. 7, Issue 5.

17. Korkach, H. Investigation of changes of structural-mechanical properties of fatty filling for synbiotic wafers [Text] / H. Korkach // EUREKA: Life Sciences. - 2017. - Issue 5. - P. 61-68. doi: 10.21303/2504-5695.2017.00427

18. Cheikhyoussef, A. Antimicrobial proteinaceous compounds obtained from bifidobacteria: From production to their application [Text] / A. Cheikhyoussef, N. Pogori, W. Chen, H. Zhang // International Journal of Food Microbiology. - 2008. - Vol. 125, Issue 3. - P. 215-222. doi: 10.1016/j.ijfoodmicro.2008.03.012

19. Shenderov, B. A. Medicinskaya mikrobnaya ekologiya i funkcional'noe pitanie. Vol. 3. Probiotiki i funkcional'noe pitanie [Text] / B. A. Shenderov. - Moscow: Grant», 2001. - P. 40-46.

20. Biavati, B. The Family Bifidobacteriaceae [Text] / B. Biavati, P. Mattarelli // The Prokaryotes. - 2006. - P. 322-382. doi: 10.1007/ 0-387-30743-5_17

21. Piksasova, O. V. Methods of Molecular Identification as Important Tools for Control and Certification in Microbiology [Text] / O. V. Piksasova, M. A. Kornienko, Yu. D. Tsygankov, A. I. Netrusov // Electronic Juornal of Natural Sciences. - 2009. - Vol. 1. P. 35-49.

22. Kaprel'yanc, L. V. Prebiotiki: himiya, tekhnologiya, primenenie [Text] / L. V. Kaprel'yanc. - Kyiv: EnterPrint, 2015. - 252 p.

23. Korkach, A. V. Possibilities of using synbiotic complex in marshmallow technology of functional purpose [Text] / A. V. Korkach, G. V. Krusir, I. A. Borovik // Eastern-European Journal of Enterprise Technologies. - 2014. - Vol. 2, Issue 12 (68). - P. $127-133$. doi: 10.15587/1729-4061.2014.23665

24. Korkach, H. Development of innovative technologies of fondant candies with synbiotics [Text] / H. Korkach, G. Krusir // Technology audit and production reserves. - 2017. - Vol. 1, Issue 3 (33). - P. 50-55. doi: 10.15587/2312-8372.2017.93806

25. Moshfegh, A. J. Presence of inulin and oligofructose in the diets of Americans [Text] / A. J. Moshfegh, J. E. Friday, J. P. Goldman // Juornal Nutrition. - 1999. - Issue 129. - P. 1407-1411. 